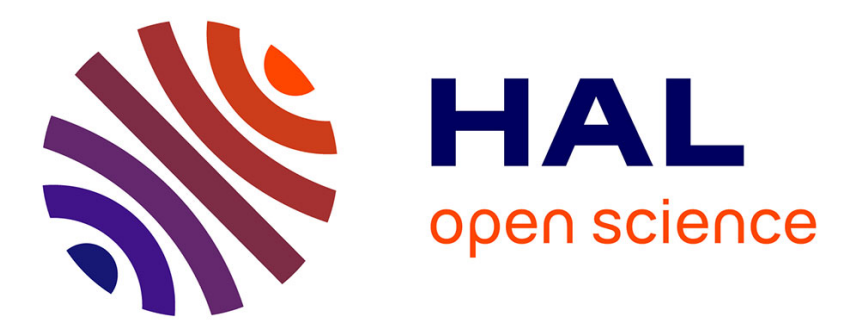

\title{
Microbial degradation of hydrophobic emerging contaminants from marine sediment slurries (Capbreton Canyon) to pure bacterial strain
}

Alyssa Azaroff, Mathilde Monperrus, Carole Miossec, Claire Gassie, Remy Guyoneaud

\section{To cite this version:}

Alyssa Azaroff, Mathilde Monperrus, Carole Miossec, Claire Gassie, Remy Guyoneaud. Microbial degradation of hydrophobic emerging contaminants from marine sediment slurries (Capbreton Canyon) to pure bacterial strain. Journal of Hazardous Materials, 2021, 402, pp.123477. 10.1016/j.jhazmat.2020.123477 . hal-02920577

\section{HAL Id: hal-02920577 \\ https://hal.science/hal-02920577}

Submitted on 27 Aug 2020

HAL is a multi-disciplinary open access archive for the deposit and dissemination of scientific research documents, whether they are published or not. The documents may come from teaching and research institutions in France or abroad, or from public or private research centers.
L'archive ouverte pluridisciplinaire HAL, est destinée au dépôt et à la diffusion de documents scientifiques de niveau recherche, publiés ou non, émanant des établissements d'enseignement et de recherche français ou étrangers, des laboratoires publics ou privés. 


\title{
Microbial degradation of hydrophobic emerging contaminants from marine sediment slurries (Capbreton Canyon) to pure bacterial strain
}

\author{
Alyssa Azaroff $^{\mathrm{a}}$, Mathilde Monperrus ${ }^{\mathrm{a}}$, Carole Miossec ${ }^{\mathrm{a}}$, Claire Gassie ${ }^{\mathrm{b}}$, Rémy Guyoneaud ${ }^{\mathrm{b}, *}$ \\ ${ }^{a}$ Université de Pau et des Pays de l'Adour, E2S UPPA, CNRS, IPREM-MIRA, UMR 5254, 64600, Anglet, France \\ ${ }^{\mathrm{b}}$ Université de Pau et des Pays de l'Adour, E2S UPPA, CNRS, IPREM-MIRA, Environmental Microbiology, UMR 5254, 64000, Pau, France
}

Despite emerging contaminants (ECs) are more and more monitored in environmental matrices, there is still a lack of data in marine ecosystems, especially on their fate and degradation potentials. In this work, for the first time, the degradation potential of synthetic musks (galaxolide and tonalide), UV filters (padimate $\mathrm{O}$ and octo-crylene) and a pharmaceutical compound (carbamazepine) was studied in marine sediment samples, under laboratory conditions using sediment slurry incubations under biotic and abiotic conditions. Minimum half life times under biotic conditions were found at 21 days, 129 days and 199 days for padimate $\mathrm{O}$, galaxolide and carbamazepine, respectively. Enrichments conducted under anoxic and oxic conditions demonstrated that de-gradations after one month of incubation either under both biotic and abiotic conditions were limited under anoxic conditions compared to oxic conditions for all the contaminants. Novel aerobic bacteria, able to degrade synthetic musks and UV filters have been isolated. These novel strains were mainly related to the Genus Bacillus. Based on these results, the isolated strains able to degrade such ECs, can have a strong implication in the natural resilience in marine environment, and could be used in remediation processes.

\section{Introduction}

As a result of the last century, Man created and is still creating new synthetic substances. Although well known persistent organic contaminants, such as organochlorine pesticides or polycyclic aromatic hydrocarbons, are regulated in industrialized countries (European Commission, US, Japan) for several decades, regulation for emerging contaminants (ECs) arised only in the early of the 21th century and

\footnotetext{
* Corresponding author.

E-mail address: remy.guyoneaud@univ-pau.fr (R. Guyoneaud).
} 


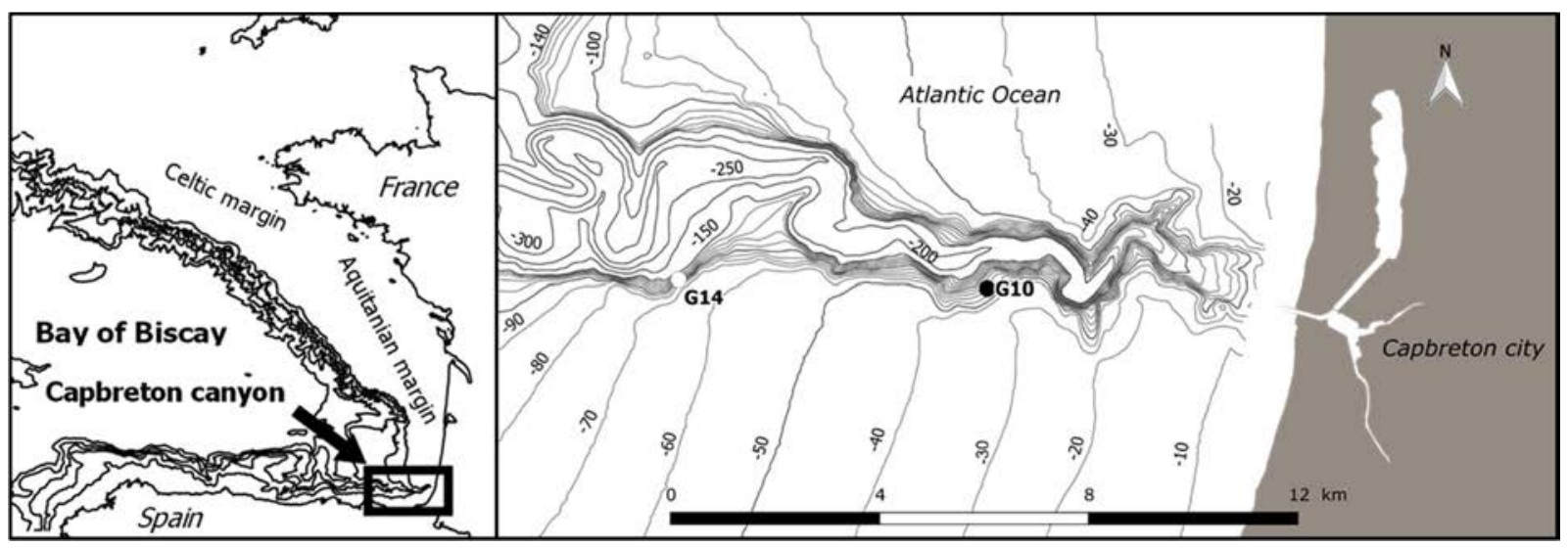

Fig. 1. Sediment sampling sites in the Capbreton Canyon (dark circle) and on the adjacent continental shelf (white circle). Isobath data from SEDIMAQ3 (Gillet 2012).

their update is still ongoing in Europe (Directive 2008/105/EC and Commission implementing decision 2018/840). Indeed, the scarce information available of their occurrence, reactivity and impact have led to a rising interest in identifying and screening these new compounds in the environment (Field et al., 2006). Among those ECs, pharmaceuticals and personal care products (PPCPs) are substances widely consumed and continuously released in the environment, mainly through wastewater, both treated and untreated (Li, 2014; Rainieri et al., 2017).

Marine ecosystem is the final receptor for these organic ECs. They were found in marine sediments, mainly close to the high density population coast nearby the main estuaries (Beretta et al., 2014; Huang et al., 2016; Pintado-Herrera et al., 2017; Azaroff et al., 2020).

Marine sediments act as integrative matrices reflecting the pollution state in a given area (Bellas et al., 2011; Roberts, 2012). The affinities of contaminants with the suspended particulate matter (SPM) lead them to be readily scavenged from the water column and to be deposited in the sediments. Submarine canyons are known to act as transfer zones of suspended particulate matter and contaminants between the continent and the open ocean where organic pollutants can be accumulated (Azaroff et al., 2020; Paull et al., 2002; Costa et al., 2011) into these productive ecosystems containing important stocks of commercially important fishes. Capbreton Canyon is located nearby the coast, with important urban and agricultural activities.

Indeed, since the Capbreton canyon is connected to the Adour estuary, its geomorphology and the local currents lead to transfer particles and micropollutants further, amplified during storm events (e.i. turbidic currents) (Mulder et al., 2001; Salles et al., 2008; Brocheray et al., 2014). For instance, in the Capbreton canyon sediments collected in the first $25 \mathrm{~km}$ from the coast, UV filters and synthetical musks have been detected where the highest concentrations were observed in sediment collected at $25 \mathrm{~km}$ from the coast (Azaroff et al., 2020). This trend was also observed for mercury compounds (Azaroff et al., 2019). Additionally, wastewater treatment plants (WWTPs) are known to be an important pathway for introduction of ECs both through the treated effluents and particles released in aquatic environment (Miège et al., 2009; Verlicchi et al., 2012). In coastal areas, those WWTPs might be the main source of ECs in coastal and submarine sediments (Azaroff et al., 2020).

Microorganisms play a key role in ecological processes such as biogeochemical cycling and among them the carbon cycle and the organic compounds degradation. This bioremediation provides an important ecosystem service for the maintenance of the environment quality. The physicochemical properties of the sediment, such as organic carbon, grain size or $\mathrm{pH}$, drive most of its interactions with the contaminants (Nowell et al., 2013). The bioavailability for the dwelling benthic organisms of these ECs is dependent on the adsorption, desorption and transformation processes which are themselves under control of the biogeochemical parameters. Even at low concentrations, those ECs can be hazardous for the sediment-dwelling benthic organisms. It is widely accepted that their microbial co-metabolization could be the main degradation pathway leading to limited structural changes and incomplete mineralization (e.g. formation of degradation products). Consequently, the fates of ECs in submarine canyon sediments depend on physicochemical properties, and on the presence and activity of microorganisms

Several studies were performed to explore bioremediation by microorganisms of priority contaminants such as polycyclic aromatic hydrocarbons (PAHs) and polychlorinated biphenyl (PCBs) (Perelo, 2010; Duran and Cravo-Laureau, 2016). Few studies have shown the potential of bacteria and microbial consortia involvement in the ECs remediation (Ncibi et al., 2017). Biotransformation potential of ECs in natural and oceanic environments is still unknown and it is urgent to better understand their fate in marine ecosystems (Gavrilescu et al., 2015).

The aim of this present work was to study the degradation potentials of ECs such as synthetic musks (galaxolide, HHCB; tonalide, AHTN), UV filters (padimate O, OD-PABA; octocrylene, OC) and an antiepileptic (carmabazepine, CBZ) in marine sediments in order to highlight, for the first time their natural resilience in a submarine canyon sediments. Moreover, a specific focus was put on the isolation of pure strains exposed to these hazardous substances in order to estimate their capacities in biotransformation of these contaminants in natural ecosystems and more particularly in marine sediments

\section{Material and methods}

\subsection{Study area and sampling strategy}

The Capbreton Canyon (South-Eastern Bay of Biscay, NE Atlantic) begins $250 \mathrm{~m}$ from the coastline and reaches up to $3000 \mathrm{~m}$ water depth. In this study, we focused on two surface sediments (G10 and G14) sampled in the Capbreton Canyon area during the oceanographic cruise HAPOGE organized in July 2017. Surface sediments $(0-10 \mathrm{~cm})$ were sampled with Shipeck sampler grab. First sampling station was into the canyon (G10) and the second one was on the adjacent continental shelf (G14) at 4.4 and $9 \mathrm{~km}$ from the coast, and at 70 and $120 \mathrm{~m}$ of depth, respectively (Fig. 1). After collection, the sediment samples were placed into sterile polyethylene bags sealed and stored in the dark at $4{ }^{\circ} \mathrm{C}$ until slurry incubations in the laboratory (described further) within $48 \mathrm{~h}$. In parallel, for each sample, contaminants analysis and geochemical parameters were analysed (Azaroff et al., 2020, 2019). Briefly, G10 sediments were more muddy than those in G14 and were characterized with particulate organic matter of $1.60 \%$ and $0.92 \%$, respectively and fine grain size $(<63 \mu \mathrm{m})$ of $76 \%$ and $46 \%$, respectively. 

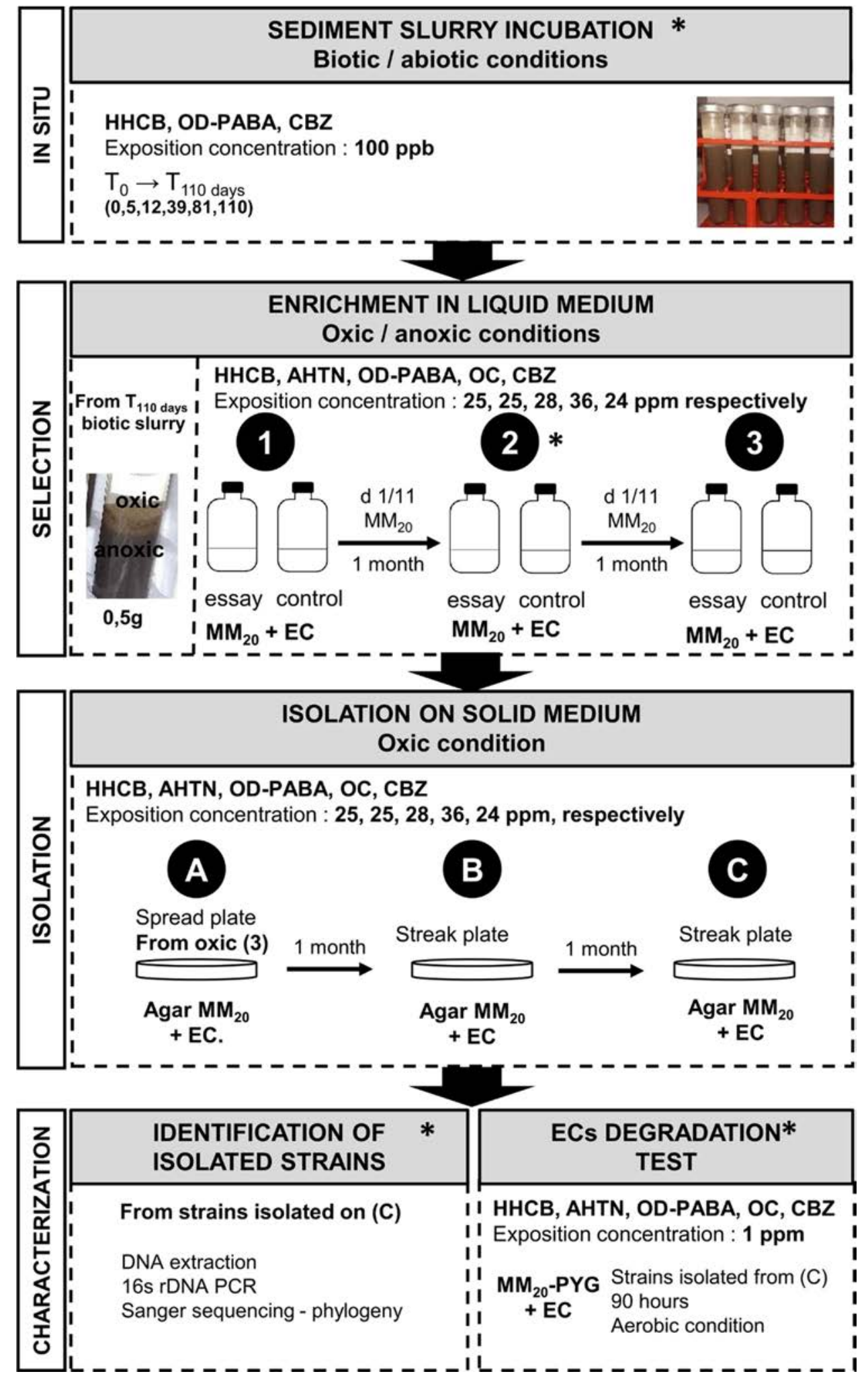

Fig. 2. Design of experiments to determine natural resilience and microbial strains involved in the degradation of emerging contaminants (ECs): Galaxolide (HHCB), Padimate O (OD-PABA), Carbamazepine (CBZ), Tonalide (AHTN) and Octocrylen (OC). First step was the determination of in situ degradation constant rates from slurry sediments spiked with three ECs under biotic and abiotic conditions at $100 \mathrm{ppb}$ (AHTN and OC were not monitored). Second step was the selection of strains from the last slurry sediments incubation (day 110) through enrichments performed under oxic/ anoxic and biotic/abiotic conditions at 25, 25, 28, 36 and 24 ppm of HHCB, AHTN, OD-PABA, $\mathrm{OC}$ and $\mathrm{CBZ}$, respectively (corresponding to $100 \mu \mathrm{M})$. These enrichments were repeated three times $(1,2,3)$ with liquid multipurpose medium at $20 \mathrm{gL}^{-1}$ of $\mathrm{NaCl}$, called $\mathrm{MM}_{20}$. Third step was strains isolation from the last enrichment (3) where microbial consortia were separated (spread plates) on agar $\mathrm{MM}_{20}$ at same ECs exposition concentrations than previously (A). After one month of growth, colonies were twice isolated by streak plating (B, C). The last step was the characterisation of isolated strains through both their identification and the determination of their ECs degradation capacities. Isolated strains were identified by $16 \mathrm{~s}$ rDNA amplification and Sanger sequencing. ECs degradation tests were performed at $1 \mathrm{ppm}$ of ECs using liquid $\mathrm{MM}_{20}$ suppplemented with peptone $\left(5 \mathrm{~g} \mathrm{~L}^{-1}\right)$, yeast extract $\left(2.5 \mathrm{~g} \mathrm{~L}^{-1}\right)$ and glucose $\left(5 \mathrm{~g} \mathrm{~L}^{-1}\right)$, called $\mathrm{MM}_{20}$-PYG. * indicates that results are presented in the figures.

\subsection{Chemicals}

Ethyl acetate (EtOAc) and methanol were of analytical grade and supplied by Sigma Aldrich (Saint-Louis, USA). Acetone (laboratory reagent. $99.5 \%$ ) used for cleaning the glassware was supplied by Fisher (Hampton, USA). Ultrapure water was obtained with a PURELAB Classic water purification system from Veolia (Paris, France). Reference standards of galaxolide (HHCB), octocrylene (OC), padimate O (OD-
PABA) and carbamazepine (CBZ) were purchased from Sigma-Aldrich. Tonalide (AHTN) was purchased from LGC Standards (Molsheim,

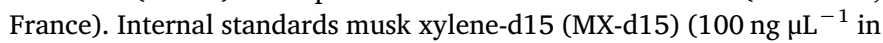
acetone) was purchased from LGC Standards and carbamazepine-d10 (CBZ-d10) (100 ng $\mu \mathrm{L}^{-1}$ in methanol) was purchased from Sigma Aldrich. 


\subsection{Determination of half life: sediment slurry incubations}

In the laboratory slurry incubations spiked with HHCB, OD-PABA and $\mathrm{CBZ}$ were performed for 110 days in order to estimate the degradation potential (Fig. 2). Briefly, for each station (G10 and G14), a slurry was prepared by mixing fresh sediment with underlying water (50:50, w:w). Incubation experiments were performed in $10 \mathrm{~mL}$ glass tubes sealed with PTFE stoppers filled with $10 \mathrm{~g}$ of slurry. For all assays under abiotic and biotic conditions, HHCB, OD-PABA and CBZ were added independently, to have a final concentration at $100 \mu \mathrm{g} \mathrm{g}^{-1}$. Initial time assays were stopped immediately by storing samples at $-80^{\circ} \mathrm{C}$ whereas incubated assays were placed in the dark at $14^{\circ} \mathrm{C}$ (in situ temperature) and stopped at different elapsed times until 110 days. Slurries under abiotic condition (control), were twice sterilized for $20 \mathrm{~min}$ at $120^{\circ} \mathrm{C}$. All assays were performed in triplicate.

Based on the assumption that degradation reaction of these contaminants are of pseudo-first-order (1),biodegradation rate constants (k) were estimated with the following Eq. (2) :

$\operatorname{Ln}(\mathrm{C})=\mathrm{f}(\mathrm{t})$

$\mathrm{k}=\operatorname{Ln}\left(\mathrm{C}_{0} / \mathrm{C}_{\mathrm{t}}\right)_{\mathrm{t}}$

Where $\mathrm{C}_{\mathrm{t}}$ is the concentration of the contaminant at the kinetic time $\mathrm{t}$; $\mathrm{C}_{0}$ is the initial contaminant concentration; $\mathrm{k}$ is the biodegradation rate constant and $\mathrm{t}$ is the time. Then, half time reactions were also determined by the following Eq. (3):

$\mathrm{t}_{1 / 2}=\operatorname{Ln}(2) / \mathrm{k}$

\subsection{Enrichment experiments in liquid medium}

In order to do a selective enrichment of microbial populations potentially involved in the ECs degradation, $0.5 \mathrm{~g}$ of oxic (surface, $0.1 \mathrm{~cm}$, clear yellow color) and $0.5 \mathrm{~g}$ of anoxic (dark color) sediments (Fig. 2) were subsamples from the last days of sediment slurry incubations and were diluted with modified multipurpose medium (Widdel and Bak, 1992) at $20 \mathrm{~g} \mathrm{~L}^{-1}$ of $\mathrm{NaCl}$, called $\mathrm{MM}_{20}$. The medium contained : $1 \mathrm{~L}$ of MilliQ water, $1 \mathrm{~mL}$ of $\mathrm{SL}_{12}, 1 \mathrm{~mL}$ SeTg, HEPES $10 \mathrm{mM}$, yeast extract $0.1 \mathrm{~g} \mathrm{~L}^{-1}, 20 \mathrm{~g} \mathrm{NaCl}, 3 \mathrm{~g} \mathrm{MgCl}_{2} 6 \mathrm{H}_{2} \mathrm{O}, 0.15 \mathrm{~g} \mathrm{CaCl}_{2} \mathrm{H}_{2} \mathrm{O}, 0.25 \mathrm{~g} \mathrm{NH}_{4} \mathrm{Cl}$, $0.5 \mathrm{~g} \mathrm{KCl}$. pH was ajusted at $\mathrm{pH}=7.5$ before sterilization and autoclave $\left(20 \mathrm{~min}\right.$ at $\left.120^{\circ} \mathrm{C}\right)$. After autoclaving, $1 \mathrm{~mL}$ of solution V7 (vitamins) and $\mathrm{KH}_{2} \mathrm{PO}_{4}$ (final concentration of $0.2 \mathrm{~g} \mathrm{~L}^{-1}$ ) were added with a syringe and a cellulose nitrate $0.2 \mu \mathrm{m}$ filter (Fisher).

While we determined the half life for 3 ECs, the enrichment experiments in liquid medium were performed for $5 \mathrm{ECs}$, HHCB, AHTN, OD-PABA, OC and CBZ. Since AHTN has the same molecular mass than HHCB but with a different chemical structure (Table 1), we performed the enrichment experiment for both from the HHCB sediment slurry incubation. Then, OC was added to this list due to its occurrence in coastal sediments (Combi et al., 2016; Mitchelmore et al., 2019). ECs were added independently at $100 \mu \mathrm{M}$ final concentration (corresponding to $25,25,28,36$ and $24 \mathrm{ppm}$, respectively) according previous experiments (Vallecillos et al., 2017; Balk and Ford, 1999; König et al., 2016; Sauvêtre et al., 2018). These ECs have low solubility in water (Table 1), and they were added first into the tube with organic solvent (EtOAc, or methanol for CBZ) and evaporated at ambient temperature, under microbiological safety cabinet (MSC). This step was performed in order to release organic solvent, a potential carbon source (Delgado-Moreno et al., 2019). Enrichment was performed in an agitator (120 rpm) (Vallecillos et al., 2017) under oxic and anoxic conditions, at $27^{\circ} \mathrm{C}$ for one month. This enrichment was repeated three times, with each time a dilution at approximatively $1 / 11$ of the previous assay. Briefly, under MSC, micropollutant was added in a falcon tube $(50 \mathrm{~mL})$ or penicillin tube $(100 \mathrm{~mL})$ (for oxic and anoxic conditions, respectively). Then $5.5 \mathrm{~mL}$ of the $\mathrm{MM}_{20}$ were added before the addition of $0.5 \mathrm{~g}$ of anoxic and oxic sediments from the slurry incubations (1 st step, Fig. 2). After one month in the agitator, new tubes were prepared with ECs by using the same protocol. Then $5 \mathrm{~mL}$ of $\mathrm{MM}_{20}$ were added and inoculated with $0.5 \mathrm{~mL}$ of the previous enrichment, corresponding to a $1 / 11$ dilution (2nd and 3rd steps, Fig. 2).

\subsection{Strains isolation experiments}

After the third enrichment step, in order to isolate the strains previously selected and enriched, solid medium of $\mathrm{MM}_{20}$ (with $20 \mathrm{~g} \mathrm{~L}^{-1}$ of agar bacteriologic, previously rinsed 3 times with ultrapure water) were prepared in Petri plates. Under MSC, micropollutants were added (274, 274, 306, 498 and $254 \mu \mathrm{L}$ of HHCB, AHTN, OD-PABA, OC and CBZ at $1000 \mathrm{ppm}$, respectively) at the surface of the solid medium and organic solvent was evaporated. Then, inocula of the last enrichments were spread at the surface of the solid medium with sterile inoculator and sealed with parafilm before incubation for 1 month, at $27^{\circ} \mathrm{C}$ to favour the growth of colonies. After one month, colonies were selected and isolated by streak plates as described (A, B, C steps, Fig. 2). Then all strains isolated were stored at $-80^{\circ} \mathrm{C}$ in sterile LB (20 g L) supplemented with $\mathrm{NaCl}\left(20 \mathrm{~g} \mathrm{~L}^{-1}\right)$, and glycerol $30 \%$ (v:v).

\subsection{Identification of isolated strains: DNA extraction, $16 s$ rDNA gene amplification, sequencing and phylogenetic analysis}

DNA was amplified from isolated strains after growth in LB Lennox medium. Amplification of the 16S rRNA gene was done with the universal primers $63 \mathrm{~F}$ ( $5^{\prime}$-CAG GCC TAA CAC ATG CAA GTC- $3^{\prime}$ ) and 1387R (5'-GGG CGG WGT GTA CAA GGC-3') (Marchesi et al., 1998). PCR amplification was performed using ampliTaq Gold $^{\circledR} 360$ master mix (Applied Biosystems, CA, USA), $0.2 \mu \mathrm{M}$ of each primer and $1 \mu \mathrm{L}$ of strain. PCR cycling was as following : after $10 \mathrm{~min}$ of initial denaturation at $95^{\circ} \mathrm{C}$ (lysis of cells), 35 cycles of $40 \mathrm{~s}$ denaturation at $95^{\circ} \mathrm{C}, 40 \mathrm{~s}$ annealing at $58^{\circ} \mathrm{C}$ and $60 \mathrm{~s}$ elongation at $72{ }^{\circ} \mathrm{C}$ with $7 \mathrm{~min}$ final elongation at $72{ }^{\circ} \mathrm{C}$. Amplicons were sequenced by SANGER sequencing at

Table 1

Characteristics of the emerging contaminants used in this study. Log $\mathrm{K}_{\mathrm{ow}}$ is octanol/water partition coefficient.

\begin{tabular}{|c|c|c|c|c|c|c|}
\hline Compound & Family & Formula & Molar mass $\mathrm{g} \mathrm{mol}^{-1}$ & Solubility in water $\mathrm{mg} \mathrm{L}^{-1}$ & $\log \mathrm{K}_{\mathrm{ow}}$ & References \\
\hline Galaxolide (HHCB) & Musk & $\mathrm{C}_{18} \mathrm{H}_{26} \mathrm{O}$ & 258.4 & 1.75 & 5.70 & (Field et al., 2006) \\
\hline Tonalide (AHTN) & Musk & $\mathrm{C}_{18} \mathrm{H}_{26} \mathrm{O}$ & 258.4 & 1.25 & 5.90 & (Field et al., 2006) \\
\hline Padimate O (OD-PABA) & UV filter & $\mathrm{C}_{17} \mathrm{H}_{27} \mathrm{NO}_{2}$ & 277.4 & 0.54 & 6.15 & $(\mathrm{Li}, 2014)$ \\
\hline Octocrylen (OC) & UV filter & $\mathrm{C}_{24} \mathrm{H}_{27} \mathrm{NO}_{2}$ & 361.5 & 0.36 & 6.88 & (Rainieri et al., 2017) \\
\hline Carbamazepine (CBZ) & Pharmaceutical & $\mathrm{C}_{15} \mathrm{H}_{12} \mathrm{~N}_{2} \mathrm{O}$ & 236.3 & 17.7 & 2.45 & EPA's EPI Suite ${ }^{\mathrm{TM}}$ \\
\hline
\end{tabular}


GATC (Köln, Germany). Sequences were trimmed with ChromasPro (Technelysium software) and were aligned with MUSCLE (Edgar, 2004).A tree was generated using MEGA X software (Kumar et al., 2018), with the Maximum Likelihood method and Tamura-Nei model (Tamura and Nei, 1993) (with n replication boostraps $=500$ ). Phylogenetic analysis were processed with NCBI (https://www.ncbi.nlm.nih. gov/) and corresponding reference type strains as defined by the bacteriological code of nomenclature for Prokaryotes (http://www. bacterio.net/-classifphyla.html). Sequences are archived in GenBank under accession numbers MT658667 to MT658707.

In parallel, in order to compare with the isolated strains, DNA of in situ samples and from the final kinetic time of the slurry incubations were studied to determine the global diversity. DNA was extracted from frozen sediments with the QIAGEN DNeasy Powersoil kits (Qiagen Inc., Netherlands) according to the manufacturer's instructions. Diversity of the $16 \mathrm{~S}$ rDNA were determined by sequencing the V4-V5 hypervariable regions of the 16S rDNA with universal primers V4-515 F ( $5^{\prime}$ GTGYCAGCMGCCGCGGTA 3') and V5-928R (5'- ACTYAAAKGAATTGRCGGGG 3') (Parada et al., 2016; Walters et al., 2015; Wang and Qian, 2009). PCR was performed using ampliTaq Gold ${ }^{\circledR} 360$ master mix (Applied Biosystems, CA, USA), $0.5 \mu \mathrm{M}$ of each primer and $3 \mathrm{ng}$ of extracted DNA. PCR cycling was as following : after $10 \mathrm{~min}$ of initial denaturation at $95^{\circ} \mathrm{C}, 30$ cycles of $30 \mathrm{~s}$ denaturation at $95{ }^{\circ} \mathrm{C}, 30 \mathrm{~s}$ annealing at $60^{\circ} \mathrm{C}$ and $40 \mathrm{~s}$ elongation at $72{ }^{\circ} \mathrm{C}$ with $7 \mathrm{~min}$ final elongation at $72{ }^{\circ} \mathrm{C}$. Amplicons were sequenced using MiSeq 250-pair-end technology (Illumina, CA, USA) with V3 kit version, in Get-plage sequencing platform (INRA, Toulouse, France). Data were preprocessed using Galaxy FROGS pipeline (Escudié et al., 2018). Chimera and PhiX reads were removed, Operational Taxonomic Units (OTUs) clustering, after a de-noising step allows building fine clusters with minimal differences, with an aggregation distance equal or above 3. Data were normalized with the minimum number of reads. Taxonomic affiliation was performed using the Silva database v.128 (Pruesse et al., 2007). Sequences data in situ and from the final kinetic time of the slurry incubations have been deposited in Genbank under the accession number PRJNA608532 and PRJNA640934, respectively.

\subsection{Experimental ECs degradation test}

Isolated strains were re-cultivated in medium $\mathrm{MM}_{20}$-PYG $\left(\mathrm{MM}_{20}\right.$ medium supplemented with peptone, $5 \mathrm{~g} \mathrm{~L}^{-1}$, yeast extracts, $2.5 \mathrm{~g} \mathrm{~L}^{-1}$ and glucose at $5 \mathrm{~g} \mathrm{~L}^{-1}$ ) à $37^{\circ} \mathrm{C}$ for $90 \mathrm{~h}$ (Popa et al., 2014). Optical density (DO) at $600 \mathrm{~nm}$ was measured during the growth until the maximum growth using spectrophotometer (Spectronic 20). Degradation tests were performed in glass tubes with contaminants (HHCB, AHTN, OD-PABA, OC and CBZ) evaporated (Delgado-Moreno et al. 2019) to be at $1 \mathrm{ppm}$ final concentration, with $1 \mathrm{~mL}$ of the cultivated strains, $9 \mathrm{~mL}$ of $\mathrm{MM}_{20}$-PYG at $27^{\circ} \mathrm{C}$ in agitator $(120 \mathrm{rpm})$ (Vallecillos et al., 2017; Popa et al., 2014). $10 \mu \mathrm{L}$ of micropollutant at $1000 \mathrm{ppm}$ were added with sterile syringe and PTFE filter $0.2 \mu \mathrm{m}$ (Fisher). Degradation was stopped when $\mathrm{DO}_{600}$ reached the maximum value. For initial and final times, chemical analysis were performed (in triplicates) to evaluate the ECs degradation capacity of the isolated strains under controlled conditions (described below).

\subsection{ECs analysis}

HHCB, AHTN, OD-PABA, OC and CBZ were extracted by a liquid:liquid extraction, for both the second enrichment in liquid medium (3) and the ECs degradation test (Fig.2) at the initial and final time of each experiment. Briefly, 10 and $2 \mathrm{~mL}$ of EtOAc were added directly into the essay tube before to vortex for $1 \mathrm{~min}$, respectively. Then, $20 \mu \mathrm{L}$ of the supernatant was diluted with EtOAc $(960 \mu \mathrm{L})$ in GC-vial and spiked with $20 \mu \mathrm{L}$ of an internal standard mixture at $10 \mu \mathrm{Lng}^{-1}$ (CBZ-d10 and MXd15) before analysis. Extracts were analysed by 7890A gas chromatograph coupled with 5975C mass spectrometer (GC/MS) with an Electron
Ionization (EI) source using a Large Volume Injection (LVI) (Agilent Technologies). The GC/MS system was equipped with a single taper ultra-inert liner with glass wool and a HP-5MS UI capillary column $(30 \mathrm{~m}$ length $\times 0.25 \mathrm{~mm}$ diameter and $0.25 \mu \mathrm{m}$ film thickness). Carrier gas was helium (He) with a purity greater than $99.999 \%$ (Linde). Separation was performed at a constant He flow of $1.5 \mathrm{~mL} \mathrm{~min}^{-1}$, and the GC oven temperature was programmed to hold at $50^{\circ} \mathrm{C}$ for $3 \mathrm{~min}$, then increase at $25^{\circ} \mathrm{C} \mathrm{min}{ }^{-1}$ until $195^{\circ} \mathrm{C}$ (hold $1.5 \mathrm{~min}$ ), then $8{ }^{\circ} \mathrm{C} \mathrm{min}^{-1}$ until $265^{\circ} \mathrm{C}$ (hold

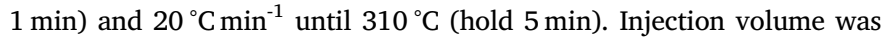
$20 \mu \mathrm{L}$ in splitless mode. Instrument control, data acquisition and data treatment were performed using Agilent Chemstation software. Quantification was carried out in Selected Ion Monitoring (SIM) mode, selecting two characteristics fragments ions for each compound. Calibrations with the target analytes (HHCB, AHTN, OD-PABA, OC and CBZ) were used to quantify target compounds. A six-point calibration curve was performed in EtOAc spiked with increasing pollutants concentration levels ranging from 0 to $500 \mu \mathrm{L} \mathrm{L}^{-1}$ as well as internal standards at $50 \mu \mathrm{g}$ $\mathrm{L}^{-1}$ transferred into GC vials (analytical performances are compiled in Table S1, supporting information). Recoveries achieved for all target ECs in $\mathrm{MM}_{20}$ medium spiked at $100 \mu \mathrm{g} \mathrm{L}^{-1}$ ranged from $91 \%$ to $102 \%$ for musk and UV-filter compound and was at $74 \%$ for CBZ (Supplementary information, Table S1).

\section{Results and discussion}

\subsection{Degradation of $H H C B, O D-P A B A$ and $C B Z$ in sediment slurry incubations}

Based on kinetic degradation for 110 days under both abiotic and biotic conditions (Supplementary information, Fig. S1), degradation rate constants, $\mathrm{k}$, were estimated from slurry incubations under biotic condition (Table 2). While CBZ in both sediment samples exhibited similar rates $(0.0035 \pm 0.0004$ and $0.0029 \pm 0.0001)$, HHCB and OD-PABA exhibited different rates of degradation according the location (e.g. G10 and G14) with a factor around 2 (Table 2). This suggested that ECs degradations were depending on the geochemical parameters of the sediments (e.i. grain size, organic matter content). For instance, a previous study demonstrated that ECs have a strong affinity for particles (Li et al., 2016), as observed with sludge in wastewater treatment plants (Liu et al., 2012), suggesting those parameters and as well as environmental factors have to be taken in consideration to understand the fate of ECs in the ocean. Estimation of the half life time of reaction for these ECs indicated that the UV filter OD-PABA was between $21 \pm 1$ and $44 \pm 4$ days (Table 2). These results are similar with another UV filter degradation (i.e. EH-DPAB) estimated in marine sediments microcosm with a $t_{1 / 2}$ ranging from 18 to 50 days (Volpe et al., 2017). Nevertheless, half life reaction for synthetic musk HHCB and anti-epileptic CBZ reached around 8 months and 7 months, respectively, indicated the high persistence of these contaminants in natural marine sediments compare to the UV filter OD-PABA (Table 2). Lack of data on HHCB and CBZ degradation

\section{Table 2}

First-order rate constants $\mathrm{k}$ (in days ${ }^{-1}$ ) for degradation of HHCB, OD-PABA and CBZ in the slurry sediments incubations under biotic condition (in triplicate). Pearson determination coefficients ranged from 0.76 to 0.98 and p-values < 0.05 for estimation of $\mathrm{k}$. The corresponding half-lives $\left(\mathrm{t}_{1 / 2}\right.$, in days) were calculated as $\ln (2) / k$. G10 and G14 correspond to canyon surface sediment and continental shelf sediment, respectively.

\begin{tabular}{llll}
\hline Emerging contaminants & Slurry incub. & $\mathrm{k} \pm \mathrm{SD}\left(\right.$ days $\left.^{-1}\right)$ & $\mathrm{t}_{1 / 2} \pm \mathrm{SD}$ (days) \\
\hline HHCB & G10 & $0.0032 \pm 0.0005$ & $224 \pm 41$ \\
& G14 & $0.0065 \pm 0.0029$ & $129 \pm 44$ \\
OD-PABA & G10 & $0.0324 \pm 0.0014$ & $21 \pm 1$ \\
& G14 & $0.0158 \pm 0.0014$ & $44 \pm 4$ \\
CBZ & G10 & $0.0035 \pm 0.0004$ & $199 \pm 19$ \\
& G14 & $0.0029 \pm 0.0001$ & $231 \pm 17$ \\
\hline
\end{tabular}




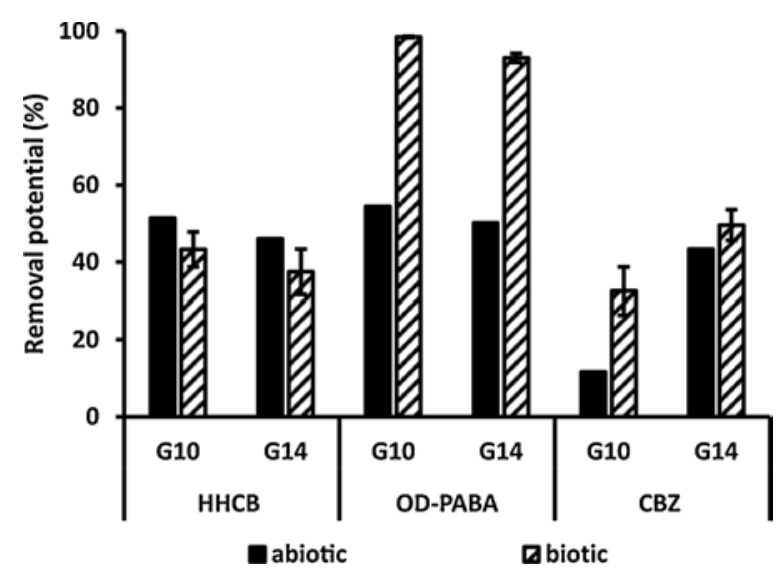

Fig. 3. HHCB, OD-PABA and CBZ removal potential (\%) after 110 days of sediment incubation ()under biotic and abiotic conditions from Capbreton Canyon sediments (G10, and G14). Initial exposure concentration was $100 \mathrm{ppb}$. Data are mean \pm SD of three replicates.

potentials in marine sediments does not allow comparison with these present data. Nevertheless, these preliminary results demonstrate the high persistence of these ECs in natural environment. In sediments, ECs may be associated to particulate matter, establishing equilibrium relations in the water-sediment interface, limiting their bioavailability. ECs remobilisation depends both of geochemical characteristics variations of the sediment, the overlying water column and pore water. Thus, ECs persistence in environment depend on coupling of abiotic and biotic factors (Lee Wolfe and Macalady, 1992; Jeon et al., 2016), such as physicochemical properties of the ECs, environmental factors (e.i. temperature (Lange et al., 2015), pH (Perelo, 2010), redox processes (Jeon et al., 2013) photolysis process (Chiron et al., 2006; Vogna et al., 2004)) and the presence of microbial communities able to degrade these ECs (Onesios et al., 2009). It was also demonstrated that bioturbation or resuspension improved oxidation of anoxic sediments leading an increase of lability of ECs which can be more available for degradation processes (Booij et al., 1992).

Additionally, chemical characterization of the collected sediments revealed that the three-targeted ECs were not found at concentration detectable with the analytical method used (Azaroff et al., 2020). The removal potential was observed under both abiotic and biotic conditions with percentage of removal for each compounds, HHCB, OD-PABA and $\mathrm{CBZ}$, ranging from $37.5 \%-51.4 \%$, from $50.1 \%-98.5 \%$ and from $11.6 \%-49.6 \%$, respectively (Fig. 3). Results of HHCB and CBZ slurry incubations suggested that the degradation was mainly driven by an abiotic process (except for G10 exposed with CBZ). Removal potential of OD-PABA under biotic condition was 2 times higher compared to the abiotic condition, suggesting that micro-organisms in these sediments improved the degradation of this UV filter compound (Fig. 3).

\subsection{Enrichment in liquid medium}

Results of the second enrichment in liquid medium (Fig. 4) demonstrated a higher removal in oxic conditions than under anoxic conditions for the five ECs studies (e.i. HHCB, AHTN, OD-PABA and CBZ). These ECs are well known to be observed in WWTP, where CBZ is frequently detected in the liquid effluents while the other contaminants, due to the very hydrophobicity, occur in sludges or remain through membrane post-treatment (Krzeminski et al., 2017). Although new advanced treatment processes, such as activated carbon adsorption, advanced oxidation processes, reverse osmosis or membrane bioreactors, are developed to increase the micropollutant removal of the WWTPs to struggle against the spread of micropollutants in aquatic environment, they are still observed in the WWTP effluents (Luo et al., 2014). Those results suggested that oxic processes could improve the ECs removal and limit their spread from the WWTP sewage. Moreover, higher removals under abiotic anoxic conditions than biotic were observed. It is likely due to a higher ECs adsorption on cells present in biotic condition leading to trap ECs and reduce the quality of the liquid extraction (Bell and Tsezos, 1987; Tsezos and Bell, 1989). Additionally, the high concentrations (ppm level) used for the selection of strains in these enrichments could inhibit microbial activity, thus could have mask their ECs removal capacities under anoxic condition (Barra Caracciolo et al., 2015).

Under oxic condition, similar removal potentials were observed for the abiotic and biotic condition, except for OC and CBZ (Fig. 4). That may indicate a potential involvement of microorganisms in the $\mathrm{OC}$ removal. Contrary to OC, CBZ removal was observed only in abiotic anoxic condition, likely due to the same explanations suggested previously for the removal potential under anoxic condition (e.i. adsorption on cells and/or high exposition concentrations). These

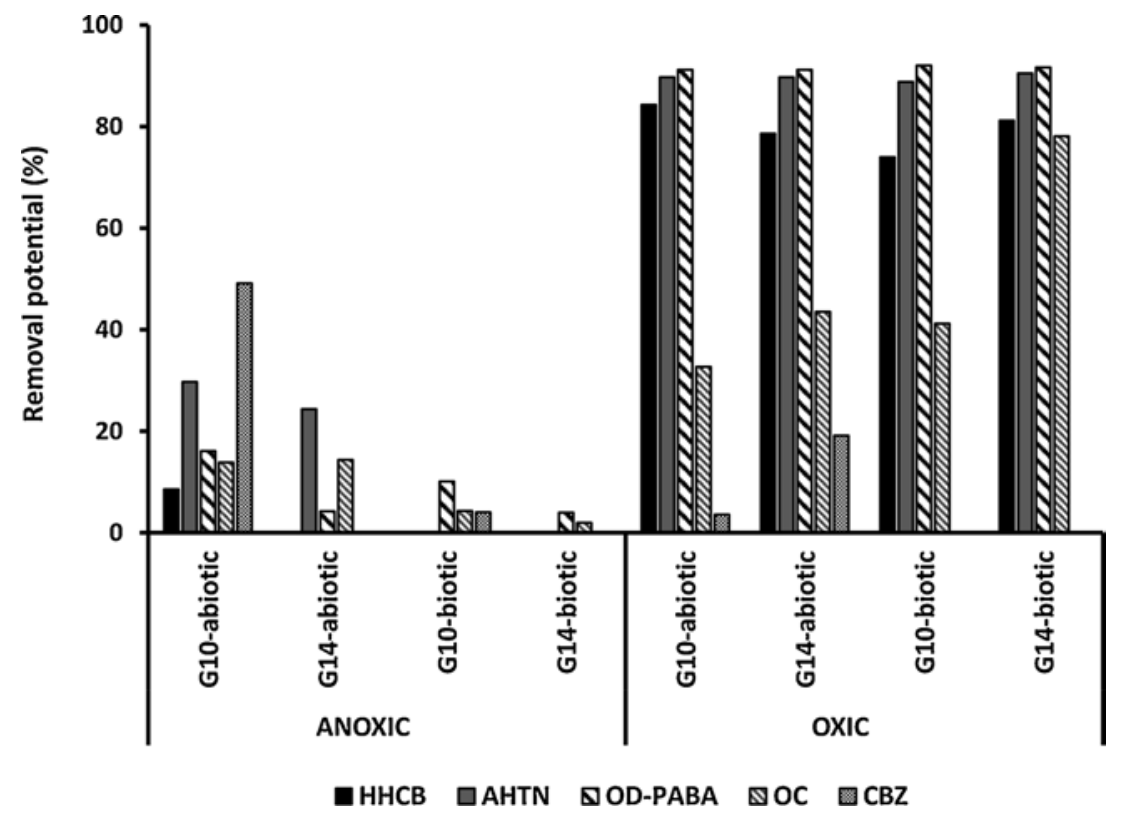

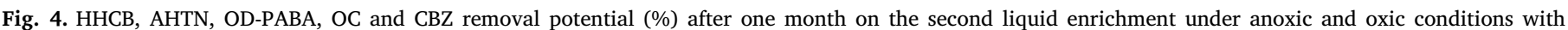
inoculum from G10 and G14 stations (biotic). Abiotic control was achieved without innoculum. 
results led to continue the study of ECs degradation with the isolated strains under oxic conditions.

Nevertheless, even though an efficient removal of ECs under oxic condition was observed, metabolites were not studied. Indeed, degradation of ECs to metabolites have been observed for CBZ (König et al., 2016), HHCB (Vallecillos et al., 2017) and also for others UV filters (Volpe et al., 2017). These results highlighted the complexity of
ECs removal under experimental conditions as well as in WWTPs, where their efficiency are dependant of both physical, chemical and biological processes but also to identify metabolites in further studies.

\subsection{Isolated strains involved in ECs degradation}
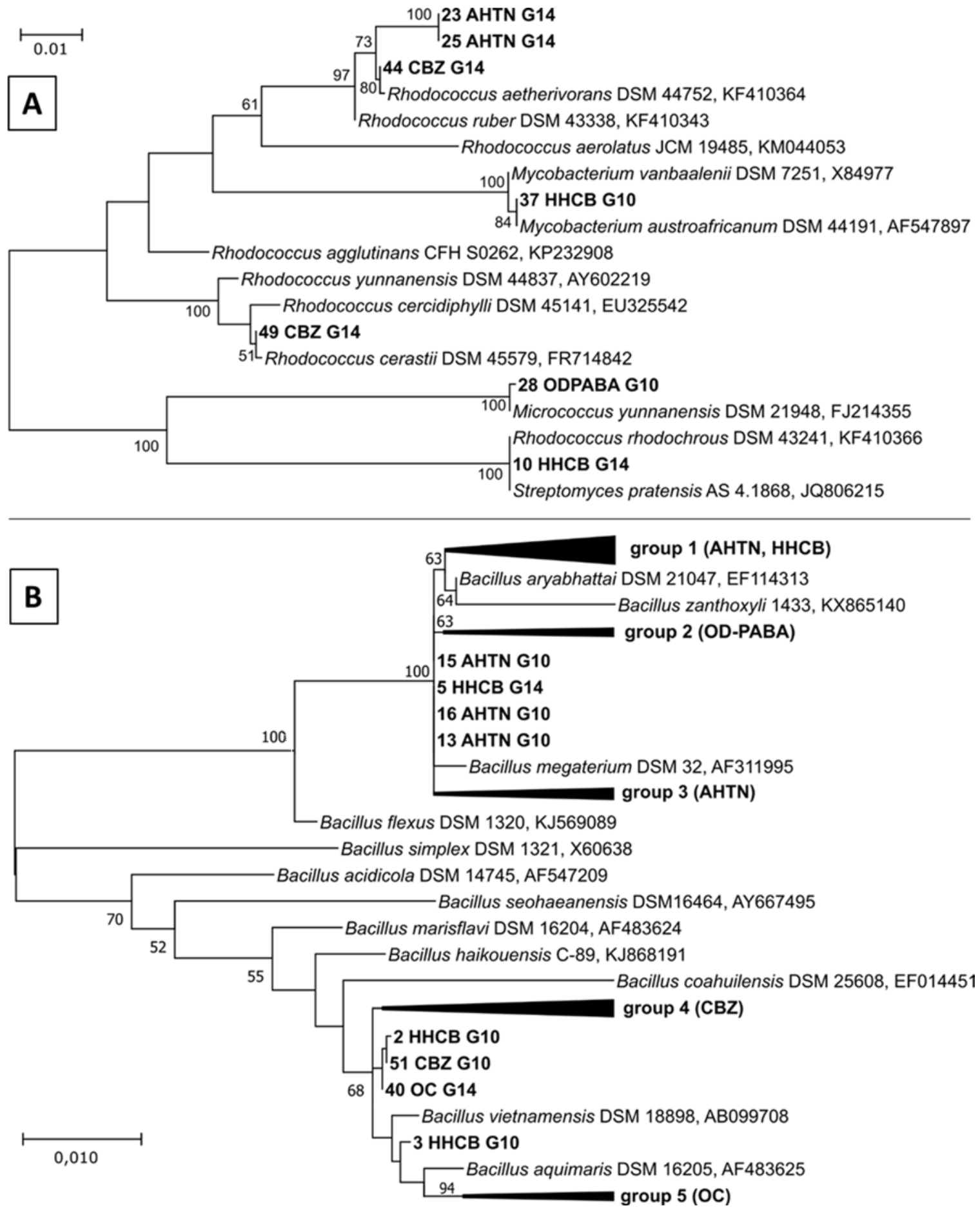

Fig. 5. Phylogenic trees of strains obtained after the aerobic isolation in solid medium with different ECs (AHTN, HHCB, OC, OD-PABA and CBZ) from sediments collected in the submarine Canyon of Capbreton (stations G10 and G14). Fig.5A and Fig.5B correspond to Actinobacteria and Firmicutes, respectively. Isolated strains are in bold, reference strains are in italic. The evolutionary history was inferred by using the Maximum Likelihood method and Tamura-Nei model. The bootstrap values areabove $50 \%$ are shown next to the branches. The scale indicates nucleotides substitution. Groups 1, 2, 3, 4 and 5 included 10 (20, 21 AHTN-G10; 22 , 27 AHTN-G14 and 4, 6, 7, 8, 11, 12 HHCB- G14), 3 (33, 35, 36 ODPABA-G14), 4 (17, 18, 19 AHTN-G10 and 24 AHTN-G14), 6 (45, 46, 47, 48 CBZ-G14 and 50, 52 CBZG10) and $3(41,42,43$ OC-G10) isolated strains, respectively. 
While the degradation of complex organic substances can occurs both under anaerobic and aerobic conditions, it is well known that their degradation rates can be higherunder aerobic condition (Biel-Maeso et al., 2019; Ying et al., 2007). In accordance with this observation, isolation of strains and degradation test were consequently performed under aerobic condition. Twenty seven strains were isolated with the current method with 6, 8, 4, 4 and 5 strains constrained with HHCB, AHTN, OD-PABA, OC and CBZ, respectively (Supplementary information, Fig. S3). These strains were related to two families, dominated by the Firmicutes, followed by the Actinobacteria (Fig. 5 A B).

Within the Actinobacteria, Rhodococcus was the main bacteria genus isolated followed by Streptomyces, Mycobacterium and Micrococcus. Within the Firmicutes, only Bacillus-related strains were isolated (Fig. 5 A, B). Studies have shown that Actinobacteria were involved in degradation of some organic and inorganic compounds. For instance, Rhodococcus strains are involved in the removal of pharmaceutical compounds (Ivshina et al., 2018), tetrabromobisphenol A (TBBPA) (Xu et al., 2018) and dominant in naphthalene degrading enrichments (Rhee et al., 2004). It has also been demonstrated that the members of the genus Streptomyces produce laccase (i.e. ligninolytic enzymes) that can be involved in the removal of recalcitrant and ECs (Majeau et al., 2010). It has also been demonstrated that members of the genus Streptomyces were involved in the CBZ biodegradation (Popa et al., 2014; Popa Ungureanu et al., 2015). Finally, experiments performed from marine sediments demonstrated that Bacillus thuringiensis was a novel group participating to the removal of PAHs and pesticides (Ferreira et al., 2016).

Within these isolated strains, only eight exhibited a capacity to degrade contaminants in the conditions used ( 1 ppm, 5 days, 37 degrees in rich organic medium) with 1, 2, 3 and 2 strains for HHCB, AHTN, OD-PABA and OC, respectively (Table 3 ). Seven were related to the

\section{Table 3}

Removal capacity of isolated strain and their related affiliation based on phylogenetic tree (Fig. 5). \% of removal is calculated relatively to the control removal and in triplicate, after $120 \mathrm{~h}$ of experimentation at $1 \mathrm{ppm}$ exposition concentration for each emerging contaminants. The strains for which degradation were not determined are not shown (Fig. 5).

\begin{tabular}{llll}
\hline Isolated strains & Phyla & Family & $\%$ of removal \pm SD \\
\hline 2 HHCB G10 & Firmicutes & Bacillus & $44 \pm 31$ \\
17 AHTN G10 & Firmicutes & Bacillus & $68 \pm 9$ \\
23 AHTN G14 & Actinobacteria & Rhodoccocus & $20 \pm 7$ \\
33 ODPABA G14 & Firmicutes & Bacillus & $34 \pm 19$ \\
35 ODPABA G14 & Firmicutes & Bacillus & $45 \pm 9$ \\
36 ODPABA G14 & Firmicutes & Bacillus & $71 \pm 19$ \\
40 OC G14 & Firmicutes & Bacillus & $17 \pm 17$ \\
43 OC G10 & Firmicutes & Bacillus & $14 \pm 13$ \\
\hline
\end{tabular}

genus Bacillus and one was related to the genus Rhodoccocus (23 AHTN G14). While studies have demonstrated high bioremediation capacities by Actinobacteria, this study demonstrated high capacity of marine $b a$ cillus to degrade ECs. These results suggested that the isolated bacillus were able to remove OD-PABA with a capacity ranging between 34 $\% \pm 19 \%$ and $71 \% \pm 19 \%$ (Table 3 ). These strains could be involved in the biotic degradation observed in the slurry incubation experiment (Fig. 3). Although CBZ slurry incubations experiments (G10) demonstrated a possible biotic degradation (Fig. 3), isolated strains did not exhibit a remediation for this pollutant under the conditions tested (Supplementary information, Fig. S3). Moreover, the $t_{1 / 2}$ of CBZ was estimated around 7 months, suggesting that the time should be expanded to observe a remediation capacity. Moreover, it is well known that in nature, the microbial consortia have to be considered to estimate biodegradation pollutant removal process (Wu et al., 2010).Moreover, global microbial communities analysed in situ, in G10 and G14 demonstrated a relative abundance of the main phyla similar in both sediments (and similar to the final kinetic time of the slurry incubations, Supplementary information Fig. S2), with a dominance of Proteobacteria (relative abundance ranged between 47.9 and $49.4 \%$ ), followed by Bacteriodetes, Planctomycetes and Acidobacteria (Fig. 6). Although the Actinobacteria and Firmicutes were minors in situ (Fig. 6), representing less than $1 \%$ of the total abundance, phylogenic trees based the sequences of the isolated strains (Fig. 5 A,B) demonstrated that these isolated strains were related to the Actinobacteria and Firmicutes families. This suggests a good selection process of these bacterial groups in the presence of these ECs exposition with the isolation method used.In accordance with previous studies, the isolated bacterial strains from the Capbreton Canyon sediments could be good candidate to degrade ECs. Nevertheless, in order to estimate the natural resilience of those ECs, it is crucial also to take account both the biological (e.i. biodegradation, biosorption/adsorption), physical and chemical processes, highlighting further studies are needed to decipher their fate in oceans. It is difficult to extrapolate results based on pure strains to the field. The culture conditions used (medium, temperature, ...) enhance some microorganisms and inhibit others. The role of co-metabolisms in microbial consortia is extremely important as well as the role of the uncultivated prokaryotes. But the objective of this study in fine to isolate strains on which we will be able to work on. The isolated strains can be a fantastic tool since they can be used to study the degradation products, to study the isotopic fractionation due to micro-organisms, or to study the genetic determinism of this pathway. These data could then be used as new tools for new environmental studies (compound specific isotopic fractionation, functional genes, ...).

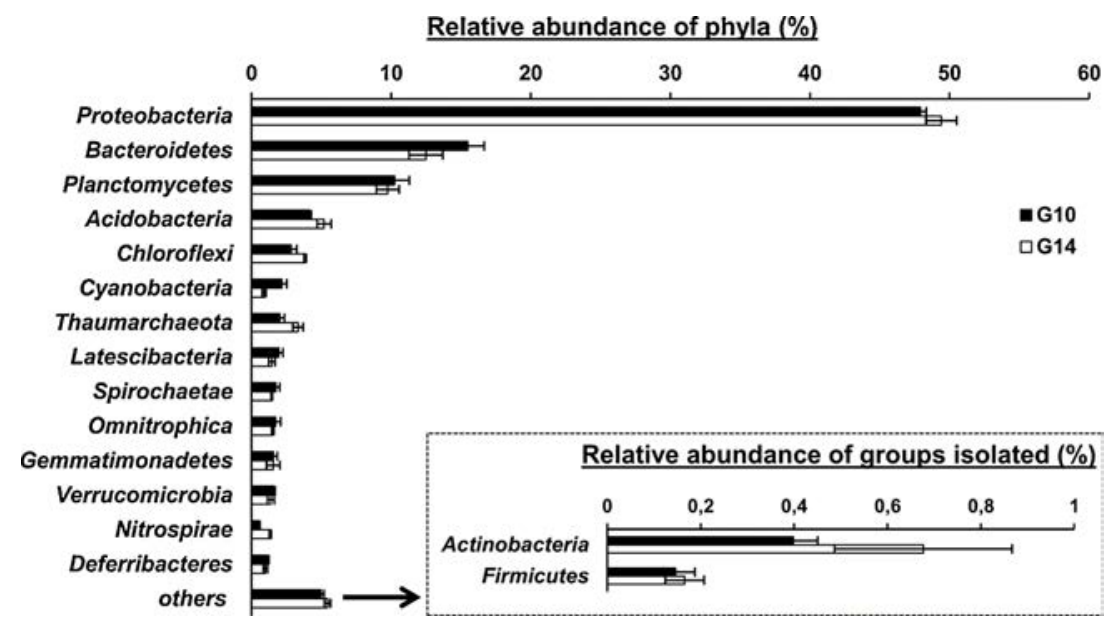

Fig. 6. Relative abundance of prokaryotic $16 \mathrm{~S}$ rDNA gene sequences (MiSEQ) from sediments of G10 and G14. Data are average percentages ( \pm SE). Categories representing $>1 \%$ are shown. Relative abundances of phyla from which the isolated strains belonged are also shown. 


\section{Conclusion}

This work characterized the degradation kinetics for ECs (HHCB, OD-PABA and CBZ) from marine sediments under in situ conditions (biotic, anaerobic and temperature) thought slurry sediment incubations. The half life times obtained demonstrated that half time live of OD-PABA was lower than HHCB and CBZ, with $t_{1 / 2}$ ranging from few weeks to 8 months. This underlies that the ECs degradation in marine sediment is a long process and could be a high concern for the environment considering a chronical contamination from the coastal human activities (e.i. WWTPs sewage, agriculture...). Additionally, contrary to CBZ, different half lives were observed between muddy (G10) and sandy (G14) sediments for HHCB and OD-PABA. That indicates ECs degradation depends on the physicochemical properties of both chemicals and sediment.

Moreover, novel synthetic musks and UV filters degrading bacteria were isolated from marine sediment. Based on phylogenetic characteristics, microorganisms were mainly identified as Bacillus sp. dominated by Bacillus megaterium followed by Bacillus aquimaris and Bacillus vietnamensis. One other isolated strain which was able to degrade musk was related to Rhodococcus ruber. The isolated bacteria here, could have a strong potential to degrade a wide variety of organic pollutants (e.g. priority and emerging), such as synthetic musks and UV filters. Improving the knowledge about the microbial diversity in marine environment may lead to the development of technical tools with degradation abilities and high tolerance in the future but also highlight how microbial remediation contributes to the nature resilience in marine environment.

\section{Author statement}

All person who meet authorship criteria are listed as authors, and all authors certify that they have participated sufficiently in the work to take public responsibility for the content, including participation in the concept, design, analysis, writing, or revision of the manuscript. Furthermore, each author certifies that this material or similar material has not been and will not be submitted to or published in any other publication before its appearance in the Journal of Hazardous Material

Specific contributions made by each author (list the authors' initials) :

R.G., A.A., designed research; M.M., R.G. acquired funding; A.A., R.G., M.M., C.M., C.G. collected data ; A.A., R.G., C.M.,C.G. analyzed data; A.A, R.G. wrote the paper, A.A., R.G., M.M reviewed and edited the paper. All authors have read and agreed with the published version of the manuscript.

\section{Declaration of Competing Interest}

The authors declare that they have no conflict of interest.

\section{Acknowledgements}

This work was supported by the European Union and the Adour Garonne Water Agency (Micropolit Project). Europe commits the New Aquitaine with the European Regional Development Fund.

\section{Appendix A. Supplementary data}

Supplementary material related to this article can be found, in the online version, at doi:https://doi.org/10.1016/j.jhazmat.2020.123477.

\section{References}

Azaroff, A., Tessier, E., Deborde, J., Guyoneaud, R., Monperrus, M., 2019. Mercury and methylmercury concentrations, sources and distribution in submarine canyon sediments (Capbreton, SW France): implications for the net methylmercury production.
Sci. Total Environ. 673, 511-521. https://doi.org/10.1016/j.scitotenv.2019.04.111. Azaroff, A., Miossec, C., Lanceleur, L., Guyoneaud, R., Monperrus, M., 2020. Priority and emerging micropollutants distribution from coastal to continental slope sediments: a case study of Capbreton Submarine Canyon (North Atlantic Ocean). Sci. Total Environ. 703, 135057. https://doi.org/10.1016/j.scitotenv.2019.135057.

Balk, F., Ford, R.A., 1999. Environmental risk assessment for the polycyclic musks AHTN and HHCB in the EU: I. Fate and exposure assessment. Toxicol. Lett. 111, 57-79. https://doi.org/10.1016/S0378-4274(99)00169-1.

Barra Caracciolo, A., Topp, E., Grenni, P., 2015. Pharmaceuticals in the environment: biodegradation and effects on natural microbial communities. A review, J. Pharm. Biomed. Anal. 106, 25-36. https://doi.org/10.1016/j.jpba.2014.11.040.

Bell, J.P., Tsezos, M., 1987. Removal of hazardous organic pollutants by biomass adsorption. J. Water Pollut. Control Fed. 59, 191-198.

Bellas, J., Nieto, Ó., Beiras, R., 2011. Integrative assessment of coastal pollution: development and evaluation of sediment quality criteria from chemical contamination and ecotoxicological data. Cont. Shelf Res. 31, 448-456. https://doi.org/10.1016/j.csr. 2010.04.012.

Beretta, M., Britto, V., Tavares, T.M., da Silva, S.M.T., Pletsch, A.L., 2014. Occurrence of pharmaceutical and personal care products (PPCPs) in marine sediments in the Todos os Santos Bay and the north coast of Salvador, Bahia, brazil. J. Soils Sediments 14, 1278-1286. https://doi.org/10.1007/s11368-014-0884-6.

Biel-Maeso, M., González-González, C., Lara-Martín, P.A., Corada-Fernández, C., 2019. Sorption and degradation of contaminants of emerging concern in soils under aerobic and anaerobic conditions. Sci. Total Environ. 666, 662-671. https://doi.org/10. 1016/j.scitotenv.2019.02.279.

Booij, K., Achterberg, E.P., Sundby, B., 1992. Release rates of chlorinated hydrocarbons from contaminated sediments. Neth. J. Sea Res. 29, 297-310. https://doi.org/10. 1016/0077-7579(92)90070-U.

Brocheray, S., Cremer, M., Zaragosi, S., Schmidt, S., Eynaud, F., Rossignol, L., Gillet, H., 2014. 2000years of frequent turbidite activity in the Capbreton Canyon (Bay of Biscay). Mar. Geol. 347, 136-152. https://doi.org/10.1016/j.margeo.2013.11.009.

Chiron, S., Minero, C., Vione, D., 2006. Photodegradation processes of the antiepileptic drug carbamazepine, relevant to estuarine waters. Environ. Sci. Technol. 40, 5977-5983. https://doi.org/10.1021/es060502y.

Combi, T., Pintado-Herrera, M.G., Lara-Martin, P.A., Miserocchi, S., Langone, L., Guerra, R., 2016. Distribution and fate of legacy and emerging contaminants along the Adriatic Sea: a comparative study. Environ. Pollut. 218, 1055-1064. https://doi.org/ 10.1016/j.envpol.2016.08.057.

Costa, A.M., Mil-Homens, M., Lebreiro, S.M., Richter, T.O., de Stigter, H., Boer, W., Trancoso, M.A., Melo, Z., Mouro, F., Mateus, M., Canário, J., Branco, V., Caetano, M., 2011. Origin and transport of trace metals deposited in the canyons off Lisboa and adjacent slopes (Portuguese Margin) in the last century. Mar. Geol. 282, 169-177. https://doi.org/10.1016/j.margeo.2011.02.007.

Delgado-Moreno, L., Bazhari, S., Nogales, R., Romero, E., 2019. Innovative application of biobed bioremediation systems to remove emerging contaminants: adsorption, degradation and bioaccesibility. Sci. Total Environ. 651, 990-997. https://doi.org/10. 1016/j.scitotenv.2018.09.268.

Duran, R., Cravo-Laureau, C., 2016. Role of environmental factors and microorganisms in determining the fate of polycyclic aromatic hydrocarbons in the marine environment. FEMS Microbiol. Rev. 40, 814-830. https://doi.org/10.1093/femsre/fuw031.

Edgar, R.C., 2004. MUSCLE: multiple sequence alignment with high accuracy and high throughput. Nucleic Acids Res. 32, 1792-1797. https://doi.org/10.1093/nar/ gkh340.

Escudié, F., Auer, L., Bernard, M., Mariadassou, M., Cauquil, L., Vidal, K., Maman, S., Hernandez-Raquet, G., Combes, S., Pascal, G., 2018. FROGS: Find, Rapidly, OTUs with Galaxy Solution. Bioinforma. Oxf. Engl. 34, 1287-1294. https://doi.org/10. 1093/bioinformatics/btx791.

Ferreira, L., Rosales, E., Danko, A.S., Sanromán, M.A., Pazos, M.M., 2016. Bacillus thuringiensis a promising bacterium for degrading emerging pollutants, process Saf Environ. Prot. 101, 19-26. https://doi.org/10.1016/j.psep.2015.05.003.

Field, J.A., Johnson, C.A., Rose, J.B., 2006. What is "emerging"? Environ. Sci. Technol. 40https://doi.org/10.1021/es062982z. 7105-7105.

Gavrilescu, M., Demnerová, K., Aamand, J., Agathos, S., Fava, F., 2015. Emerging pollutants in the environment: present and future challenges in biomonitoring, ecological risks and bioremediation. New Bioeth. 32, 147-156. https://doi.org/10.1016/j. nbt.2014.01.001.

Huang, W., Xie, Z., Yan, W., Mi, W., Xu, W., 2016. Occurrence and distribution of synthetic musks and organic UV filters from riverine and coastal sediments in the Pearl River estuary of China. Mar. Pollut. Bull. 111, 153-159. https://doi.org/10.1016/j. marpolbul.2016.07.018.

Ivshina, I., Tyumina, E., Vikhareva, E., 2018. Biodegradation of emerging pollutants: focus on pharmaceuticals. Microbiol. Aust. 39, 117-122. https://doi.org/10.1071/ MA18037.

Jeon, J.-R., Murugesan, K., Nam, I.-H., Chang, Y.-S., 2013. Coupling microbial catabolic actions with abiotic redox processes: a new recipe for persistent organic pollutant (POP) removal. Biotechnol. Adv. 31, 246-256. https://doi.org/10.1016/j. biotechadv.2012.11.002.

Jeon, J.-R., Murugesan, K., Baldrian, P., Schmidt, S., Chang, Y.-S., 2016. Aerobic bacterial catabolism of persistent organic pollutants - potential impact of biotic and abiotic interaction. Curr. Opin. Biotechnol. 38, 71-78. https://doi.org/10.1016/j.copbio. 2015.12.016.

König, A., Weidauer, C., Seiwert, B., Reemtsma, T., Unger, T., Jekel, M., 2016. Reductive transformation of carbamazepine by abiotic and biotic processes. Water Res. 101, 272-280. https://doi.org/10.1016/j.watres.2016.05.084.

Krzeminski, P., Schwermer, C., Wennberg, A., Langford, K., Vogelsang, C., 2017. Occurrence of UV filters, fragrances and organophosphate flame retardants in 
municipal WWTP effluents and their removal during membrane post-treatment. J. Hazard. Mater. 323, 166-176. https://doi.org/10.1016/j.jhazmat.2016.08.001.

Kumar, S., Stecher, G., Li, M., Knyaz, C., Tamura, K., 2018. MEGA X: Molecular Evolutionary Genetics Analysis across Computing Platforms. Mol. Biol. Evol. 35, 1547-1549. https://doi.org/10.1093/molbev/msy096.

Lange, C., Kuch, B., Metzger, J.W., 2015. Occurrence and fate of synthetic musk fragrances in a small German river. J. Hazard. Mater. 282, 34-40. https://doi.org/10. 1016/j.jhazmat.2014.06.027.

Lee Wolfe, N., Macalady, D.L., 1992. New perspectives in aquatic redox chemistry: abiotic transformations of pollutants in groundwater and sediments. J. Contam. Hydrol. 9, 17-34. https://doi.org/10.1016/0169-7722(92)90048-J.

Li, W.C., 2014. Occurrence, sources, and fate of pharmaceuticals in aquatic environment and soil. Environ. Pollut. 187, 193-201. https://doi.org/10.1016/j.envpol.2014.01. 015.

Li, S., Lu, G., Xie, Z., Ding, J., Liu, J., Li, Y., 2016. Sorption and degradation of selected organic UV filters (BM-DBM, 4-MBC, and OD-PABA) in laboratory water-sediment systems. Environ. Sci. Pollut. Res. 23, 9679-9689. https://doi.org/10.1007/s11356016-6126-2.

Liu, Y.-S., Ying, G.-G., Shareef, A., Kookana, R.S., 2012. Occurrence and removal of benzotriazoles and ultraviolet filters in a municipal wastewater treatment plant Environ. Pollut. 165, 225-232. https://doi.org/10.1016/j.envpol.2011.10.009. 1987.

Luo, Y., Guo, W., Ngo, H.H., Nghiem, L.D., Hai, F.I., Zhang, J., Liang, S., Wang, X.C., 2014. A review on the occurrence of micropollutants in the aquatic environment and their fate and removal during wastewater treatment. Sci. Total Environ. 473-474, 619-641. https://doi.org/10.1016/j.scitotenv.2013.12.065.

Majeau, J.-A., Brar, S.K., Tyagi, R.D., 2010. Laccases for removal of recalcitrant and emerging pollutants. Bioresour. Technol. 101, 2331-2350. https://doi.org/10.1016/ j.biortech.2009.10.087.

Marchesi, J.R., Sato, T., Weightman, A.J., Martin, T.A., Fry, J.C., Hiom, S.J., Wade, W.G., 1998. Design and evaluation of useful bacterium-specific PCR primers that amplify genes coding for bacterial 16S rRNA. Appl Env. Microbiol. 64, 795-799.

Miège, C., Choubert, J.M., Ribeiro, L., Eusèbe, M., Coquery, M., 2009. Fate of pharmaceuticals and personal care products in wastewater treatment plants - conception of a database and first results. Environ. Pollut. 157, 1721-1726. https://doi.org/10.1016/ j.envpol.2008.11.045.

Mitchelmore, C.L., He, K., Gonsior, M., Hain, E., Heyes, A., Clark, C., Younger, R., Schmitt-Kopplin, P., Feerick, A., Conway, A., Blaney, L., 2019. Occurrence and distribution of UV-filters and other anthropogenic contaminants in coastal surface water, sediment, and coral tissue from Hawaii. Sci. Total Environ. 670, 398-410. https://doi.org/10.1016/j.scitotenv.2019.03.034.

Mulder, T., Weber, O., Anschutz, P., Jorissen, F., Jouanneau, J.-M., 2001. A few monthsold storm-generated turbidite deposited in the Capbreton Canyon (Bay of Biscay, SW France). Geo-Mar. Lett. 21, 149-156. https://doi.org/10.1007/s003670100077.

Ncibi, M.C., Mahjoub, B., Mahjoub, O., Sillanpää, M., 2017. Remediation of emerging pollutants in contaminated wastewater and aquatic environments: biomass-based technologies. Clean (Weinh) 45, 1700101. https://doi.org/10.1002/clen.201700101.

Nowell, L.H., Moran, P.W., Gilliom, R.J., Calhoun, D.L., Ingersoll, C.G., Kemble, N.E., Kuivila, K.M., Phillips, P.J., 2013. Contaminants in stream sediments from Seven United States metropolitan areas: part I: distribution in relation to urbanization. Arch. Environ. Contam. Toxicol. 64, 32-51. https://doi.org/10.1007/s00244-0129813-0.

Onesios, K.M., Yu, J.T., Bouwer, E.J., 2009. Biodegradation and removal of pharmaceuticals and personal care products in treatment systems: a review. Biodegradation. 20, 441-466. https://doi.org/10.1007/s10532-008-9237-8.

Parada, A.E., Needham, D.M., Fuhrman, J.A., 2016. Every base matters: assessing small subunit rRNA primers for marine microbiomes with mock communities, time series and global field samples. Environ. Microbiol. 18, 1403-1414. https://doi.org/10 1111/1462-2920.13023.

Paull, C.K., Greene, H.G., Ussler, W., Mitts, P.J., 2002. Pesticides as tracers of sediment transport through Monterey Canyon. Geo-Mar. Lett. 22, 121-126. https://doi.org/10 1007/s00367-002-0110-1.

Perelo, L.W., 2010. Review: In situ and bioremediation of organic pollutants in aquatic sediments. J. Hazard. Mater. 177, 81-89. https://doi.org/10.1016/j.jhazmat.2009. 12.090 .

Pintado-Herrera, M.G., Wang, C., Lu, J., Chang, Y.-P., Chen, W., Li, X., Lara-Martín, P.A., 2017. Distribution, mass inventories, and ecological risk assessment of legacy and emerging contaminants in sediments from the Pearl River Estuary in China. J. Hazard. Mater. 323, 128-138. https://doi.org/10.1016/j.jhazmat.2016.02.046.

Popa, C., Favier, L., Dinica, R., Semrany, S., Djelal, H., Amrane, A., Bahrim, G., 2014.
Potential of newly isolated wild Streptomyces strains as agents for the biodegradation of a recalcitrant pharmaceutical, carbamazepine. Environ. Technol. 35, 3082-3091. https://doi.org/10.1080/09593330.2014.931468.

Popa Ungureanu, C., Favier, L., Bahrim, G., Amrane, A., 2015. Response surface optimization of experimental conditions for carbamazepine biodegradation by Streptomyces MIUG 4.89. New Bioeth. 32, 347-357. https://doi.org/10.1016/j.nbt. 2014.12.005.

Pruesse, E., Quast, C., Knittel, K., Fuchs, B.M., Ludwig, W., Peplies, J., Glöckner, F.O., 2007. SILVA: a comprehensive online resource for quality checked and aligned ribosomal RNA sequence data compatible with ARB. Nucleic Acids Res. 35, 7188-7196. https://doi.org/10.1093/nar/gkm864.

Rainieri, S., Barranco, A., Primec, M., Langerholc, T., 2017. Occurrence and toxicity of musks and UV filters in the marine environment. Food Chem. Toxicol. 104, 57-68. https://doi.org/10.1016/j.fct.2016.11.012.

Rhee, S.-K., Liu, X., Wu, L., Chong, S.C., Wan, X., Zhou, J., 2004. Detection of genes involved in biodegradation and biotransformation in microbial communities by using 50-Mer oligonucleotide microarrays. Appl. Environ. Microbiol. 70, 4303-4317. https://doi.org/10.1128/AEM.70.7.4303-4317.2004.

Roberts, D.A., 2012. Causes and ecological effects of resuspended contaminated sediments (RCS) in marine environments. Environ. Int. 40, 230-243. https://doi.org/10. 1016/j.envint.2011.11.013.

Salles, T., Mulder, T., Gaudin, M., Cacas, M.C., Lopez, S., Cirac, P., 2008. Simulating the 1999 Capbreton canyon turbidity current with a Cellular Automata model. Geomorphology. 97, 516-537. https://doi.org/10.1016/j.geomorph.2007.09.005.

Sauvêtre, A., May, R., Harpaintner, R., Poschenrieder, C., Schröder, P., 2018. Metabolism of carbamazepine in plant roots and endophytic rhizobacteria isolated from Phragmites australis. J. Hazard. Mater. 342, 85-95. https://doi.org/10.1016/j. jhazmat.2017.08.006.

Tamura, K., Nei, M., 1993. Estimation of the number of nucleotide substitutions in the control region of mitochondrial DNA in humans and chimpanzees. Mol. Biol. Evol. 10, 512-526. https://doi.org/10.1093/oxfordjournals.molbev.a040023.

Tsezos, M., Bell, J.P., 1989. Comparison of the biosorption and desorption of hazardous organic pollutants by live and dead biomass. Water Res. 23, 561-568. https://doi org/10.1016/0043-1354(89)90022-5.

Vallecillos, L., Sadef, Y., Borrull, F., Pocurull, E., Bester, K., 2017. Degradation of synthetic fragrances by laccase-mediated system. J. Hazard. Mater. 334, 233-243. https://doi.org/10.1016/j.jhazmat.2017.04.003.

Verlicchi, P., Al Aukidy, M., Zambello, E., 2012. Occurrence of pharmaceutical compounds in urban wastewater: removal, mass load and environmental risk after a secondary treatment-a review. Sci. Total Environ. 429, 123-155. https://doi.org/ 10.1016/j.scitotenv.2012.04.028.

Vogna, D., Marotta, R., Andreozzi, R., Napolitano, A., d'Ischia, M., 2004. Kinetic and chemical assessment of the UV/H2O2 treatment of antiepileptic drug carbamazepine. Chemosphere 54, 497-505. https://doi.org/10.1016/S0045-6535(03)00757-4.

Volpe, A., Pagano, M., Mascolo, G., Grenni, P., Rossetti, S., 2017. Biodegradation of UVfilters in marine sediments. Sci. Total Environ. 575, 448-457. https://doi.org/10. 1016/j.scitotenv.2016.10.001.

Walters, W., Hyde, E.R., Berg-Lyons, D., Ackermann, G., Humphrey, G., Parada, A., Gilbert, J.A., Jansson, J.K., Caporaso, J.G., Fuhrman, J.A., Apprill, A., Knight, R., 2015. Improved bacterial 16S rRNA gene (V4 and V4-5) and fungal internal transcribed spacer marker gene primers for microbial community surveys. MSystems 1 . https://doi.org/10.1128/mSystems.00009-15.

Wang, Y., Qian, P.-Y., 2009. Conservative fragments in bacterial 16S rRNA genes and primer design for $16 \mathrm{~S}$ ribosomal DNA amplicons in metagenomic studies. PLoS One 4 e7401. https://doi.org/10.1371/journal.pone.0007401.

Widdel, F., Bak, F., 1992. Gram-negative mesophilic sulfate-reducing bacteria. In: Balows, A., Trüper, H.G., Dworkin, M., Harder, W., Schleifer, K.-H. (Eds.), Prokaryotes Handb. Biol. Bact. Ecophysiol. Isol. Identif. Appl. Springer New York, New York, NY, pp. 3352-3378. https://doi.org/10.1007/978-1-4757-2191-1_21.

Wu, Y., He, J., Yang, L., 2010. Evaluating adsorption and biodegradation mechanisms during the removal of Microcystin-RR by periphyton. Environ. Sci. Technol. 44, 6319-6324. https://doi.org/10.1021/es903761y.

Xu, S., Wang, Y.-F., Yang, L.-Y., Ji, R., Miao, A.-J., 2018. Transformation of tetrabromobisphenol A by Rhodococcus jostii RHA1: effects of heavy metals. Chemosphere. 196, 206-213. https://doi.org/10.1016/j.chemosphere.2017.12.173.

Ying, G.-G., Yu, X.-Y., Kookana, R.S., 2007. Biological degradation of triclocarban and triclosan in a soil under aerobic and anaerobic conditions and comparison with environmental fate modelling. Environ. Pollut. 150, 300-305. https://doi.org/10.1016/ j.envpol.2007.02.013. 